\title{
ANALISIS PENGARUH MUSIK KLASIK DAN MUSIK ALAM TERHADAP KUALITAS TIDUR BERDASARKAN SINYAL ELECTROENCEPHALOGRAM
}

\author{
Adriani Rizka Amalia ${ }^{1}$, \\ Fiky Yosef Suratman $^{2}$, Dwi Esti Kusumandari ${ }^{3}$, Nushratul Lailiyya ${ }^{4}$ \\ 1, 2 Fakultas Teknik Elektro, Universitas Telkom, Bandung (40257), Indonesia \\ ${ }^{3}$ Unit Pelaksana Teknis Balai Pengembangan Instrumentasi, \\ Lembaga Ilmu Pengetahuan Indonesia, Bandung (40135), Indonesia \\ ${ }^{4}$ Departement Neurology, Fakultas Kedokteran, Universitas Padjajaran, Bandung (45363), Indonesia \\ 1adrianirizka.amalia@gmail.com, ${ }^{2}$ fysuratman@telkomuniversity.ac.id, \\ 3esti_dek@yahoo.com, ${ }^{4}$ leilyantono@gmail.com
}

\begin{abstract}
Abstrak
Tidur merupakan kebutuhan dasar bagi setiap individu. Kondisi seseorang bisa dipengaruhi oleh kualitas tidurnya. Menjaga kualitas tidur penting untuk dilakukan karena dapat membantu menurunkan stress, meningkatkan mood dan fokus. Sebagian besar masyarakat meyakini bahwa pemberian stimulus musik dapat menambah kenyamanan tidur. Rangsangan suara merupakan salah satu variabel yang dapat mempengaruhi kehadiran gelombang listrik di otak, serta dapat membantu seseorang untuk merasa lebih rileks. Penelitian ini mempelajari pengaruh musik klasik dan musik alam terhadap kualitas tidur dari sinyal electroencephalogram (EEG). Sinyal EEG adalah salah satu cara untuk dapat mengetahui kualitas tidur seseorang. Kualitas tidur dipelajari melalui sinyal EEG, dengan memberikan rangsangan musik yang secara bertahap kepada individu, berdasarkan total waktu di setiap tahapan tidur, sleep latency dan efisiensi tidur. Masukan sistem merupakan sinyal yang didapat dari perekaman sinyal menggunakan sensor Mitsar EEG-202, yang pada penerapannya akan diletakkan pada 19 titik (multi channel) sesuai dengan sistem internasional 10-20. Tahap awal penelitian pengaruh stimulus musik berdasarkan sinyal EEG ini adalah akuisisi data, kemudian pembacaan data dilakukan secara visual dan telah diverifikasi oleh dokter spesialis syaraf. Setelah itu penentuan kualitas tidur ditentukan dengan melihat adanya pengaruh musik dengan metode statistik uji kesamaan dua rata-rata dan $F$-test. Hasil analisis dari 9 subjek dengan menggunakan uji kesamaan dua rata-rata menunjukkan bahwa adanya pengaruh pada Non Rapid Eye Movement (NREM). tahap 3 dengan musik klasik. Analisis $F$-test menunjukkan adanya perbedaan yang signifikan pada NREM tahap 1 dengan musik klasik maupun musik alam.
\end{abstract}

Kata Kunci: EEG, kualitas tidur, uji kesamaan dua rata-rata, $F$-test

\section{Abstract}

Sleeping is a primary need for every individual. A person's condition can be affected by the quality of his/her sleeping. Maintaining the quality of sleeping is important to decrease stress, to increase mood and to focus. With the electroencephalogram (EEG) signal, information about the state of a person's sleep quality can be determined. Most people believe music stimulus can increase the comfort of sleeping. Audio stimulation is one of the variables that affect the presence of electric waves in the brain, and can help a person to feel more relaxed. This research studied the influence of classical music and natural music on sleep quality, utilizing EEG signals, based on total time in each stage of sleep, sleep latency, and sleep efficiency. The system input is a signal obtained from measurements using electrode sensor Mitsar EEG-202, which placed at 19 points (multi channel), according to the international system 10-20. The initial stage of the system is the data acquisition, then the data visually read and verified by neurologist, after that the determination of sleep quality, by comparing the influence at the influence of music stimulus to the condition without stimulus using two averages equality test and F-test statistic method. Two average equality test analysis showed that there is an effect on NREM stage 3 with classical music, from 9 subjects. While the F-test analysis showed a significant difference in NREM stage 1 with classical music, as well as natural music.

Key Words: EEG, sleep quality, two averages quality test, F-test 


\section{Pendahuluan}

Tidur merupakan kebutuhan dasar bagi setiap individu. Kondisi seseorang dapat dipengaruhi oleh kualitas tidurnya. Menjaga kualitas tidur penting untuk dilakukan untuk membantu menurunkan stress, meningkatkan mood dan fokus. Namun, pada kenyataannya hanya sedikit orang yang memperhatikan kualitas tidur.

Otak manusia menghasilkan empat jenis sinyal dasar, yaitu Theta, Beta, Alpha dan Delta. Masing-masing sinyal tersebut memiliki frekuensi yang berbeda sesuai, dengan aktifitas yang sedang dikerjakan tubuh, yaitu frekuensi gelombang beta $14-30 \mathrm{~Hz}$, alpha $813 \mathrm{~Hz}$, theta $47 \mathrm{~Hz}$, dan delta $0,53 \mathrm{~Hz}[1]$.

Melihat dari permasalahan tersebut, diperlukan suatu alternatif yang dapat mencegah dampak negatif akibat kualitas tidur yang buruk. Pemberian rangsangan musik sering digunakan untuk terapi relaksasi, guna meningkatkan kesehatan jiwa dan pikiran [2]. Pada umumnya, musik klasik dan musik alam digunakan sebagai terapi.

Sebelumnya telah dilakukan penelitian mengenai Effect of Sundanese Music on Daytime Sleep Quality based on EEG Signal [3]. Penelitian tersebut dilakukan pada 10 subjek, 5 orang laki-laki dan 5 orang perempuan di siang hari selama 20 menit dengan musik sunda, dan ternyata pemberian musik sunda dapat memberikan rasa lebih nyaman rileks saat tidur. Penelitian lainnya yaitu pemenuhan kualitas tidur lansia di Panti Sosial Tresna Werdha Blitar [4]. Penelitian tersebut dilakukan pada 12 subjek yang sedang mengalami gangguan pemenuhan kebutuhan tidur, dan didapatkan hasil bahwa musik Langgan Jawa memberikan perbaikan kualitas tidur, dengan 8 subjek memiliki kualitas tidur yang baik dan 4 orang memiliki kualitas tidur yang cukup.

Selain pemberian stimulus musik, usia menjadi salah satu faktor yang mempengaruhi kebutuhan tidur. Kebutuhan tidur berkurang sesuai dengan pertambahan usia [5].

Tujuan penelitian ini adalah mengidentifikasi sinyal EEG yang diberi rangsangan musik dan tanpa rangsangan secara visual. Kemudian, melihat ada atau tidaknya pengaruh musik di setiap tahapan tidur, sleep latency, dan efisiensi tidur. Membandingkan efektivitas musik klasik dan musik alam dalam meningkatkan kualitas tidur.

\section{Sinyal EEG dan Kualitas Tidur}

\subsection{Electroencephalogram (EEG)}

Electroencephalogram (EEG) adalah sinyal listrik yang dihasilkan oleh aktivitas kelistrikan otak. Fenomena ini terjadi pada bagian dalam dan luar otak, sehingga sinyal bisa dideteksi di kulit kepala [1]. Neuron-neuron di dalam korteks otak mengeluarkan gelombang-gelombang listrik dengan tegangan yang sangat kecil $(\mu V)$, yang kemudian dialirkan ke mesin EEG untuk diamplifikasi, sehingga menghasilkan Sinyal EEG yang ukurannya cukup untuk dapat ditangkap oleh mata [1]. Dapat dilihat pada Tabel 1, sinyal Delta pada frekuensi $0.5-3 \mathrm{~Hz}$ menggambarkan kondisi tidur nyenyak, sinyal Theta pada frekuensi $47 \mathrm{~Hz}$ menggambarkan kondisi tidur ringan, sinyal Alpha pada frekuensi $813 \mathrm{~Hz}$ menggambarkan kondisi bangun dan rileks, sinyal Beta pada frekuensi $14 \mathrm{~Hz}$ menggambarkan kondisi bangun dan sadar.

Tabel 1. Klasifikasi Sinyal EEG

\begin{tabular}{|c|c|c|c|}
\hline $\begin{array}{l}\text { Frequensi } \\
(\mathrm{Hz})\end{array}$ & Sinyal & Kondisi & Gambar sinyal \\
\hline $0.5-3$ & Delta & $\begin{array}{c}\text { Tidur } \\
\text { nyenyak }\end{array}$ & WA \\
\hline $4-7$ & Theta & $\begin{array}{l}\text { Tidur } \\
\text { ringan }\end{array}$ & wr \\
\hline $8-13$ & Alpha & $\begin{array}{c}\text { Bangun } \\
\text { dan } \\
\text { rileks }\end{array}$ & Mannan \\
\hline 14 & Beta & $\begin{array}{l}\text { Kesadaran } \\
\text { penuh }\end{array}$ & $=-x+m$ \\
\hline
\end{tabular}

\subsection{Sleep Stage}

Tabel 2. Karakteristik Tahapan Tidur

\begin{tabular}{|c|c|}
\hline $\begin{array}{c}\text { Tahapan } \\
\text { tidur }\end{array}$ & Karakteristik tahapan \\
\hline Awake & Alpha actrity \\
\hline $\begin{array}{c}\text { NREM } \\
1\end{array}$ & 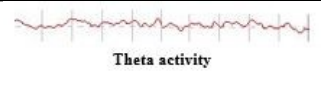 \\
\hline $\begin{array}{l}\text { NREM } \\
2\end{array}$ & 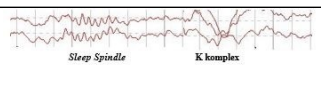 \\
\hline $\begin{array}{l}\text { NREM } \\
3\end{array}$ & Delta activity \\
\hline $\begin{array}{l}\text { NREM } \\
\quad 4\end{array}$ & Delta activity \\
\hline REM & Theta activity \\
\hline
\end{tabular}

Tahapan tidur dibagi menjadi dua fase yaitu Rapid Eye Movement (REM) dan Non Rapid Eye Movement (NREM). Tidur REM terjadi saat kita bermimpi, sedangkan NREM adalah kondisi tidur dimana bola mata tidak bergerak atau tenang [7]. Tidur NREM memiliki empat tahapan. Selama tingkatan terdalam berlangsung 
(tahapan 3 dan 4), orang tersebut akan cukup sulit dibangunkan.

Tabel 2 menunjukkan hubungan antara tahapan tidur dan aktivitas otak. Keadaan terjaga (awake) ditandai dengan munculnya gelombang alpa dan beta. NREM tahap 1, yang dianggap sebagai kondisi mengantuk, ditandai dengan munculnya gelombang theta dan alpha on-off. NREM tahap 2 memiliki ciri khusus, yaitu adanya sleep spindle dengan rentang frekuensi $12-16 \mathrm{~Hz}$ dan terletak di daerah central, meskipun terkadang mendominasi di daerah frontal [8], serta adanya $K$-complex. $K$-complex adalah gelombang besar yang bereaksi terhadap rangsangan luar saat tidur [8]. Sleep spindle berdampingan dengan $K$-complex. NREM tahap 3 dan tahap 4 dikenal dengan Slow Wave Sleep (SWS). SWS didefinisikan oleh adanya aktivitas delta selama lebih dari $20 \%$ setiap epoch, dan memiliki high amplitude $(>75 \mu \mathrm{V})[6]$. Perbedaan antara tahap 3 dan tahap 4 NREM hanya bersifat kuantitatif yang berkaitan dengan jumlah aktivitas delta. Tahap 3 didefinisikan oleh aktivitas delta yang menempati $20-50 \%$, sedangkan pada tahap 4, aktivitas delta lebih besar dari 50\% setiap epoch [6].

\subsection{Kualitas Tidur}

Kualitas tidur adalah kepuasan seseorang terhadap tidur. Kualitas tidur meliputi aspek kuantitatif dan kualitatif, seperti lamanya tidur, waktu yang diperlukan untuk bisa tertidur, frekuensi terbangun dan aspek subjektif seperti kedalaman dan kepulasan tidur [7]. The Pittsburgh Sleep Quality Index (PSQI) adalah instrumen efektif yang digunakan untuk mengukur kualitas tidur dan pola tidur pada orang dewasa [5]. PSQI dikembangkan untuk mengukur dan membedakan individu dengan kualitas tidur yang baik dan kualitas tidur yang buruk. Parameter tersebut antara lain persentase deep sleep, sleep latency, durasi tidur, efisiensi tidur, gangguan tidur, penggunaan obat tidur, dan disfungsi tidur pada siang hari [5].

Parameter yang digunakan pada penelitian ini adalah sleep latency, durasi setiap tahapan tidur dan efisiensi tidur. Semakin kecil nilai sleep latency, maka semakin baik kualitas tidurnya. Semakin besar efisiensi tidur dan semakin panjang durasi setiap tahapan tidur, maka semakin baik kualitas tidurnya. Semakin dominan pada NREM tahap 2 dan NREM tahap 3 daripada NREM tahap 1, maka semakin baik kualitas tidurnya.

\section{Metode dan Perancangan Sistem}

Sembilan orang laki-laki dengan umur 20-23 tahun telah dipilih untuk melakukan eksperimen dengan menggunakan Sensor Mitsar 202, dimana subjek akan diberi stimulus musik klasik dan musik alam. Diagram blok sistem dan skema akuisisi data pada penelitian ini diilustrasikan berturut-turut pada Gambar 1 dan Gambar 2.

Gambar 1 menjelaskan alur sistem dari penelitian ini. Masukan sistem merupakan sinyal yang didapat dari perekaman sinyal dengan 3 kondisi, yaitu kondisi tanpa stimulus, dengan stimulus musik klasik, dan stimulus musik alam. Pembacaan data dilakukan secara visual. Untuk mengetahui ada atau tidaknya pengaruh musik klasik dan musik alam, digunakan analisa statistik dengan metode $F$-test dan uji kesamaan dua rata-rata [10-11, 13-14].

\subsection{Akuisisi Data}

Seperti diilustrasikan pada Gambar 2, tahap pertama akuisisi data yang dilakukan adalah mempersiapkan ruang eksperimen dengan suasana hening dan gelap, serta dilengkapi air conditioner (AC) dengan suhu $24^{\circ} \mathrm{C}$. Tahap selanjutnya adalah pengaturan perangkat. Pengaturan perangkat terdiri dari dua bagian yaitu pengaturan perangkat keras dan pengaturan perangkat lunak. Pengaturan perangkat keras meliputi pengaturan Sensor Mitsar EEG-202. Mitsar EEG-202 sudah dilengkapi dengan amplifier dan electro-cap yang digunakan untuk merekam aktivitas sinyal EEG sebagai input sistem. Amplifier diatur dengan menggunakan perangkat lunak yang dikembangkan secara khusus.

Pengaturan perangkat lunak dilakukan menggunakan software WinEEG. WinEEG adalah perangkat lunak yang digunakan untuk menampilkan dan menyimpan hasil perekaman sinyal EEG. Untuk mendapatkan hasil yang baik, ada beberapa hal yang harus diperhatikan terlebih dahulu, di antaranya adalah montase, yang digunakan bipolar double banana sesuai dengan sistem internasional 10-20 [9].

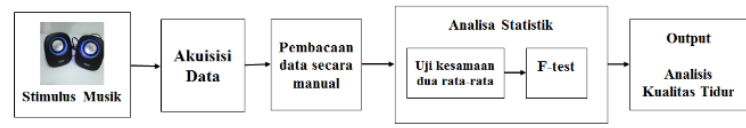

Gambar 1. Diagram Blok Sistem

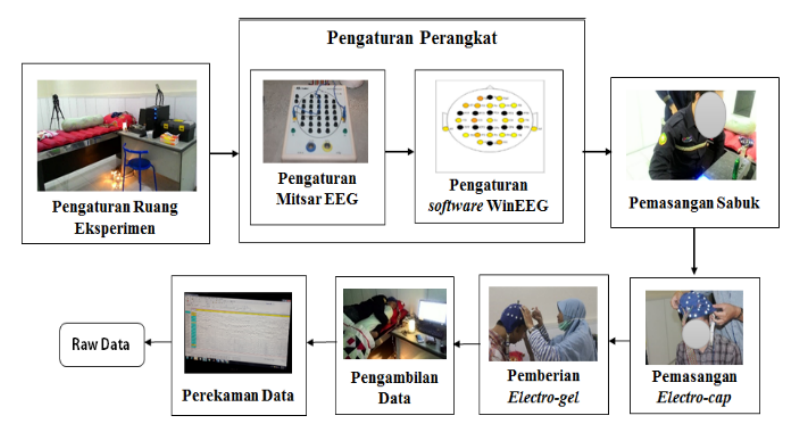

Gambar 2. Skema Akuisisi Data

Pengaturan EEG bipolar menghubungkan tiap channel elektroda dengan pola Fp1-F7, F7-T3, T3-T5, 

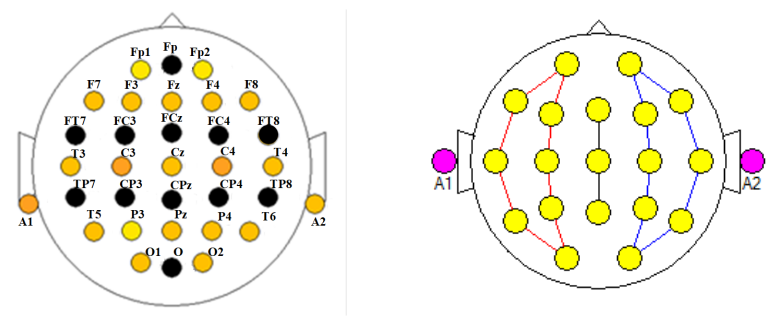

Gambar 3. Montase Bipolar

T5-O1, Fp2-F8, F8-T4, T4-T6, T6-O2, Fp1-F3, F3-C3, C3-P3, P3-O1, Fp2-F4, F4-C4, C4-P4, P4-O2, Fz-Cz, $\mathrm{Cz}-\mathrm{Pz}$, seperti ditunjukkan pada Gambar 5 [9]. Filter yang digunakan adalah Band Pass Filter (BPF), dengan low cut frequency dan High cut frequency berturut-turut $0.3 \mathrm{~Hz}-30 \mathrm{~Hz}$, dikarenakan rentang frekuensi otak manusia saat tidur berkisar pada frekuensi tersebut. Frekuensi sampling $1000 \mathrm{~Hz}$, gain (skala vertikal) 100 $\mu V$ atau $70 \mu V$, dan speed (skala horizontal) $30 \mathrm{~mm} / \mathrm{s}$. Pengambilan data dimulai sejak subjek menutup mata sampai terlelap dengan rentan waktu 90 menit (1 siklus tidur).

\subsection{Uji Kesamaan Dua Rata-Rata}

Uji kesamaan dua rata-rata adalah pengujian yang dilakukan pada penelitian dengan teknik eksperimen, dimana satu sampel diberi perlakuan tertentu, kemudian dibandingkan dengan sampel dengan perlakuan yang lain [10]. Terdapat beberapa tahap pada uji kesamaan dua rata-rata di antaranya menentukan hipotesis null, menentukan tingkat signifikansi, menentukan penggunaan uji satu sisi atau dua sisi, menentukan statistik tabel dan statisktik uji, dan pengambilan kesimpulan, dengan penjelasan sebagai berikut [11]:

1. Menentukan hipotesis null (Ho) dan hipotesis alternatif $(\mathrm{Ha})$, misalnya: $\mathrm{Ho}=$ Kedua rata-rata populasi adalah identik $(\mu 1=\mu 2$ atau $\mu 1-\mu 2=$ $0) \mathrm{Ha}=$ Kedua rata-rata populasi adalah tidak identik $(\mu 1 \neq \mu 2$ atau $\mu 1-\mu 2 \neq 0)$

2. Menentukan tingkat signifikansi $(\alpha)$, yaitu probabilitas kesalahan menolak hipotesis yang ternyata benar. Jika dikatakan $\alpha=5 \%$, berarti risiko kesalahan mengambil keputusan adalah $5 \%$. Semakin kecil $\alpha$, berarti semakin mengurangi risiko kesalahan.

3. Menentukan apakah akan dilakukan uji satu sisi atau uji dua sisi.

- Uji dua sisi jika pernyataan Ho dan Ha hanya mengandung pertidaksamaan.

- Uji satu sisi jika pernyataan Ho dan Ha mengandung pertidaksamaan yang mengarah pada kriteria tertentu.

4. Menentukan statistik tabel dan statistik uji. Dalam uji ini akan dicari $\mathrm{t}$ tabel dan $\mathrm{t}$ hitung. Untuk kondisi simpangan baku yang tidak sama $\left(\sigma_{1} \neq \sigma_{2}\right)$ nilai $\mathrm{t}$ dan $\mathrm{s}^{2}$ dihitung menggunakan persamaan (1) dan (2) sebagai berikut: [12]:

$$
t=\frac{\overline{x_{1}}-\overline{x_{2}}}{\sqrt{\left(\frac{s_{1}{ }^{2}}{n_{1}}+\frac{s_{2}{ }^{2}}{n_{2}}\right)}}
$$

$$
s^{2}=\sqrt{\frac{n \sum x_{i}^{2}-\left(\sum x_{i}\right)^{2}}{n(n-1)}}
$$

dimana, $\mathrm{s}^{2}$ menyatakan varians sampel, $\mathrm{n}$ adalah jumlah sampel, $x_{1}$ merupakan data sampel 1 , dan $x_{2}$ menunjukkan data sampel 2 .

Sedangkan nilai t tabel didapatkan dari persamaan (3) [12]:

$$
\text { t tabel }=t_{(1-1 / 2 \propto)}, \quad(n-1)
$$

dimana, $\infty$ menyatakan tingkat kepercayaan (0.05) dan $\mathrm{n}$ adalah jumlah sampel.

5. Mengambil kesimpulan berdasar hasil $\mathrm{t}$ tabel dan $\mathrm{t}$ hitung [12].

- Menerima Ho jika $t$ hitung lebih kecil daripada $t$ tabel

- Menolak Ho jika t hitung lebih besar daripada t tabel

\section{$3.3 \quad$ F-test}

F-test dikenal dengan uji ANOVA atau uji varians. Analisis varians adalah prosedur untuk menganalisis variasi dari respons atau perlakuan dan mencoba menerapkan porsi varians ini pada setiap kelompok variabel independen. Keuntungan dari penggunaan analisis varians adalah mampu melakukan perbandingan untuk banyak variabel [10].

Hasil akhir dari analisis ini adalah nilai $\mathrm{F}$ hitung. Nilai $F$ hitung ini akan dibandingkan dengan nilai pada $F$ tabel. Aturan dalam pengambilan keputusan pada $F$-test adalah menerima hipotesis null (H0) jika F hitung lebih kecil daripada $\mathrm{F}$ tabel dan menolak $\mathrm{H} 0$ jika $\mathrm{F}$ hitung lebih besar dari $\mathrm{F}$ tabel.Nilai $\mathrm{F}$ hitung dapat dicari dengan membandingkan sampel yang memiliki nilai varian yang besar $\left(S_{A}\right)$ dengan sampel yang memiliki nilai varian lebih kecil $\left(S_{B}\right)$, rumus perhitungan untuk mencari mencari $\mathrm{F}$ hitung, $S_{A}$, dan $S_{B}$ berturut-turut menggunakan persamaan (4), (5) dan (6) sebagai berikut: [13]:

$$
\begin{gathered}
F=\frac{S_{A}{ }^{2}}{S_{B}{ }^{2}} \\
S_{A}{ }^{2}=\frac{\sum\left(X_{A}-\overline{X_{A}}\right)^{2}}{n-1}
\end{gathered}
$$




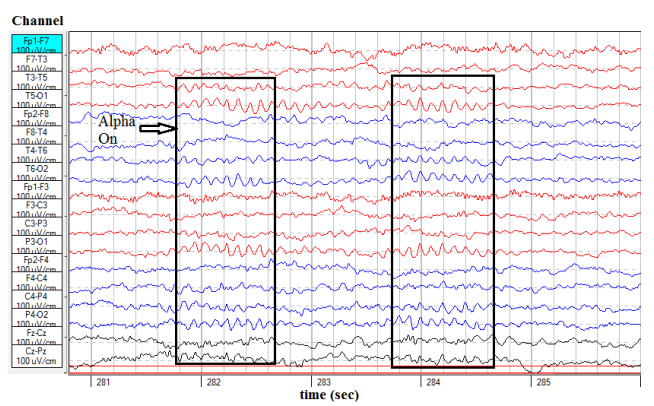

Gambar 4. Contoh Hasil Akuisisi Data

$$
S_{B}^{2}=\frac{\sum\left(X_{B}-\overline{X_{B}}\right)^{2}}{n-1}
$$

dimana $X_{A}$ dan $X_{B}$ menyatakan data sampel A dan $\mathrm{B}, \overline{x_{A}}$ dan $\overline{x_{B}}$ adalah rata-rata dari data sampel $\mathrm{A}$ dan $\mathrm{B}$, dan F merupakan nilai F hitung.

\section{Hasil dan Pembahasan}

Pada penelitian ini telah dilakukan 27 kali pengambilan data pada 9 laki-laki. Sembilan subjek tersebut tidak sedang mengkonsumsi obat dan tidak mengkonsumsi kopi. Pengambilan data dilakukan di ruangan yang sama dan terkondisi selama kurang lebih 90 menit. Pengambilan data sinyal dilakukan saat subjek memejamkan mata hingga tertidur. Pada eksperimen ini diberikan 2 stimulus, yaitu musik klasik dan musik alam. Contoh sinyal yang diperoleh saat eksperimen dapat dilihat pada Gambar 4. Gambar 4 menunjukkan ciri dari NREM tahap 2, yaitu munculnya sinyal alpha on-off.

Parameter utama untuk mengukur kualitas tidur, yaitu sleep latency, durasi setiap tahapan tidur, persentase deep sleep dan efisiensi tidur.

Gambar 5 sampai dengan Gambar 9 berturut-turut menunjukkan grafik hasil pembacaan sleep latency, NREM tahap 1, NREM tahap 2, NREM tahap 3, dan efisiensi tidur musik klasik, musik alam, dan tanpa stimulus. Pemberian musik klasik menghasilkan rata-rata sleep latency 125.56 detik sedangkan musik alam 86.56 detik. Rata-rata efisiensi tidur tanpa stimulus adalah $75,97 \%$, sedangkan musik klasik $89,41 \%$ dan musik alam 90,14\%. Dengan demikian musik klasik dapat menaikkan efisiensi tidur hingga 13,14\% dan musik alam $14,17 \%$. Tidur sambil mendengarkan musik menjadi lebih rileks dan menambah efisiensi kualitas tidur.

Berdasarkan Gambar 5 sampai dengan Gambar 9 jika dihitung rata-ratanya akan didapatkan hasil sebagai berikut. Pemberian musik klasik menghasilkan rata-rata sleep latency 125.56 detik sedangkan musik alam 86.56 detik. Rata-rata efisiensi tidur tanpa stimulus adalah $75,97 \%$, sedangkan musik klasik $89,41 \%$ dan musik alam 90,14\%. Dengan demikian musik klasik dapat
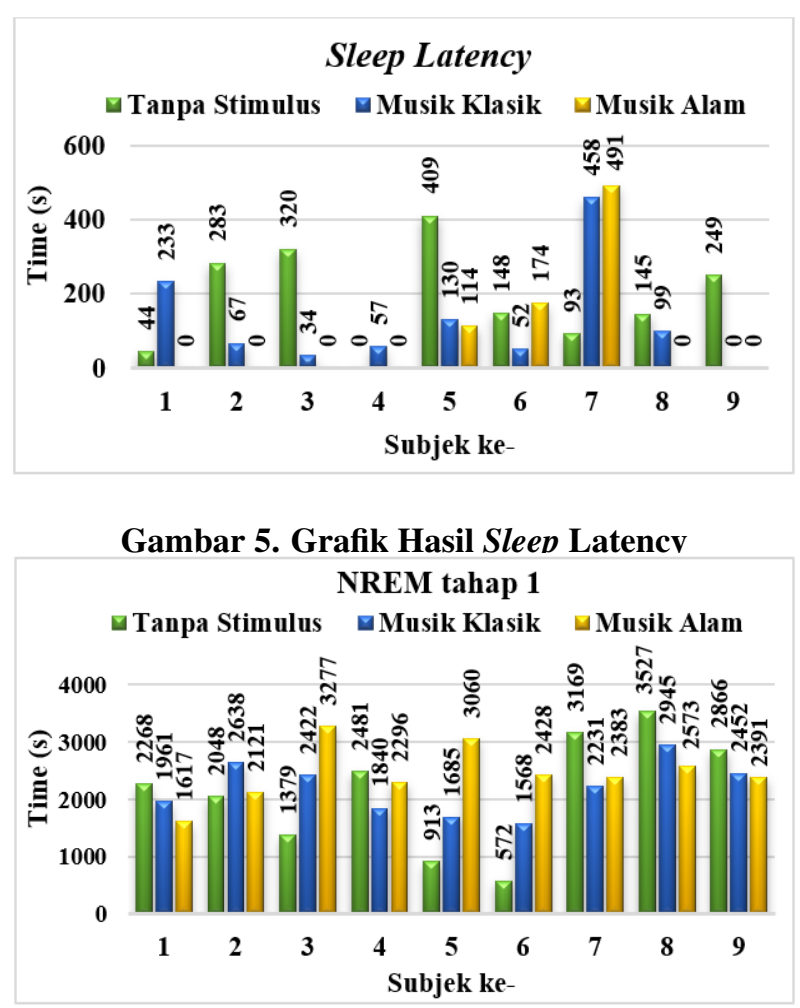

Gambar 6. Grafik Hasil NREM Tahap 1

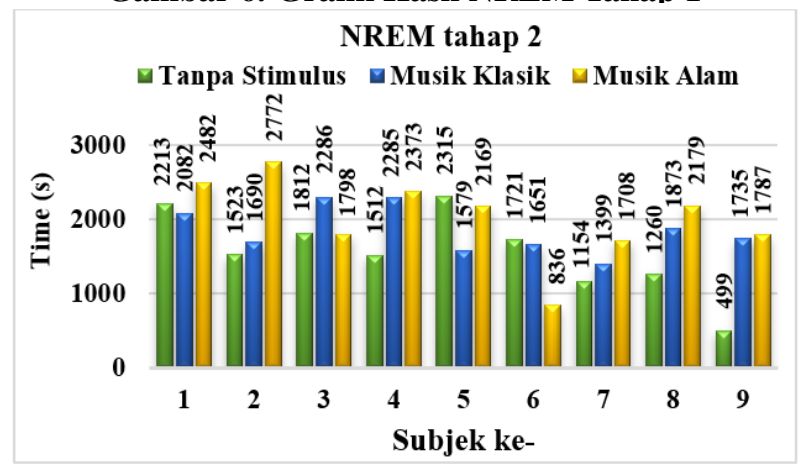

Gambar 7. Grafik Hasil NREM Tahap 2

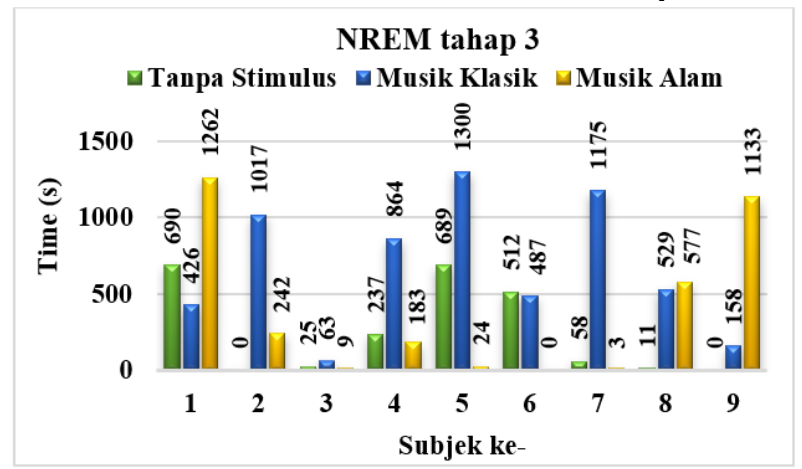

Gambar 8. Grafik Hasil NREM Tahap 3

menaikkan efisiensi tidur hingga 13,14\% dan musik alam 
Tabel 3. Kuantitatif Analisis Pengaruh Musik Alam dan Musik Klasik Pada Kualitas Tidur Setiap Subjek

\begin{tabular}{|c|c|c|c|}
\hline Subjek & Uraian singkat musik klasik & Uraian singkat musik alam & Kualitas Tidur \\
\hline 1 & 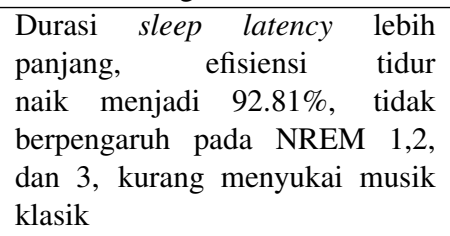 & $\begin{array}{l}\text { Durasi sleep latency lebih pendek, } \\
\text { tidur didominasi oleh NREM 2, } \\
\text { durasi NREM } 3 \text { lebih panjang } \\
\text { dibandingkan musik klasik dan } \\
\text { tanpa stimulus, efisiensi tidur } \\
99.26 \%\end{array}$ & $\begin{array}{l}\text { Kualitas tidur musik alam lebih } \\
\text { baik dibandingkan dengan tanpa } \\
\text { stimulus dan musik klasik }\end{array}$ \\
\hline 2 & $\begin{array}{l}\text { Durasi sleep latency lebih pendek, } \\
\text { tidur didominasi oleh NREM 1, } \\
\text { efisiensi tidur naik menjadi } 97.5 \%\end{array}$ & $\begin{array}{l}\text { Durasi sleep latency lebih pendek, } \\
\text { tidur didominasi oleh NREM } \\
2 \text {, efisiensi tidur naik menjadi } \\
94.01 \%\end{array}$ & $\begin{array}{l}\text { Kualitas tidur musik klasik dan } \\
\text { alam lebih baik dibandingkan } \\
\text { dengan tanpa stimulus }\end{array}$ \\
\hline 3 & $\begin{array}{l}\text { Durasi sleep latency lebih pendek, } \\
\text { tidur didominasi oleh NREM } 1 \\
\text { dan NREM 2, efisiensi tidur naik } \\
\text { menjadi } 84.35 \%\end{array}$ & $\begin{array}{l}\text { Durasi sleep latency lebih pendek, } \\
\text { tidur didominasi oleh NREM 1, } \\
\text { efisiensi tidur naik menjadi } 93.3 \%\end{array}$ & $\begin{array}{l}\text { Kualitas tidur musik klasik dan } \\
\text { alam lebih baik dibandingkan } \\
\text { dengan tanpa stimulus }\end{array}$ \\
\hline 4 & $\begin{array}{l}\text { Durasi sleep latency lebih } \\
\text { panjang, tidur didominasi oleh } \\
\text { NREM 2, durasi NREM } 3 \text { lebih } \\
\text { panjang dibandingkan musik } \\
\text { alam dan tanpa stimulus, efisiensi } \\
\text { tidur naik menjadi } 91.81 \%\end{array}$ & $\begin{array}{l}\text { Durasi sleep latency lebih } \\
\text { pendek, efisiensi tidur } 89.03 \% \text {, } \\
\text { tidur didominasi oleh NREM } 1 \\
\text { dan NREM 2, kurang menyukai } \\
\text { musik alam }\end{array}$ & $\begin{array}{l}\text { Kualitas tidur musik klasik lebih } \\
\text { baik dibandingkan dengan tanpa } \\
\text { stimulus dan musik alam }\end{array}$ \\
\hline 5 & $\begin{array}{l}\text { Durasi sleep latency lebih pendek, } \\
\text { durasi NREM } 3 \text { lebih panjang } \\
\text { dibandingkan musik alam dan } \\
\text { tanpa stimulus, efisiensi tidur naik } \\
\text { menjadi } 92.82 \%\end{array}$ & $\begin{array}{l}\text { Durasi sleep latency lebih pendek, } \\
\text { tidur didominasi oleh NREM } \\
\text { 1, efisiensi tidur naik menjadi } \\
94.48 \%\end{array}$ & $\begin{array}{l}\text { Kualitas tidur musik klasik dan } \\
\text { alam lebih baik dibandingkan } \\
\text { dengan tanpa stimulus }\end{array}$ \\
\hline 6 & $\begin{array}{l}\text { Durasi sleep latency lebih pendek, } \\
\text { tidur didominasi oleh NREM } 1 \\
\text { dan NREM 2, efisiensi tidur naik } \\
\text { menjadi } 83.79 \%\end{array}$ & $\begin{array}{lll}\text { Durasi sleep latency lebih } & \text { le } \\
\text { panjang, tidur didominasi } & \text { oleh } \\
\text { NREM 1, efisiensi tidur } & \text { naik } \\
\text { menjadi } 72.84 \% & & \\
\end{array}$ & $\begin{array}{l}\text { Kualitas tidur musik klasik dan } \\
\text { alam lebih baik dibandingkan } \\
\text { dengan tanpa stimulus }\end{array}$ \\
\hline 7 & 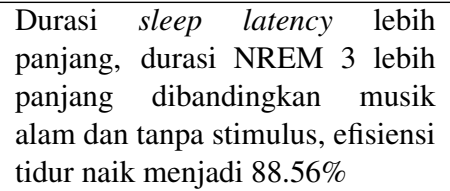 & $\begin{array}{l}\text { Durasi sleep latency lebih } \\
\text { panjang, efisiensi tidur } 75.42 \% \text {, } \\
\text { tidur didominasi oleh NREM } 1 \\
\text { dan NREM 2, kurang menyukai } \\
\text { musik alam }\end{array}$ & $\begin{array}{l}\text { Kualitas tidur musik klasik lebih } \\
\text { baik dibandingkan dengan tanpa } \\
\text { stimulus dan musik alam }\end{array}$ \\
\hline 8 & $\begin{array}{l}\text { Durasi sleep latency lebih pendek, } \\
\text { tidur didominasi oleh NREM } 1 \\
\text { dan NREM 2, efisiensi tidur naik } \\
\text { menjadi } 93.76 \%\end{array}$ & $\begin{array}{l}\text { Durasi sleep latency lebih pendek, } \\
\text { tidur didominasi oleh NREM } 1 \\
\text { dan NREM 2, efisiensi tidur naik } \\
\text { menjadi } 97.12 \%\end{array}$ & $\begin{array}{l}\text { Kualitas tidur musik klasik dan } \\
\text { alam lebih baik dibandingkan } \\
\text { dengan tanpa stimulus }\end{array}$ \\
\hline 9 & $\begin{array}{l}\text { Durasi sleep latency lebih pendek, } \\
\text { tidur didominasi oleh NREM } 1 \\
\text { dan NREM 2, efisiensi tidur naik } \\
\text { menjadi } 79.26 \%\end{array}$ & $\begin{array}{l}\text { Durasi sleep latency lebih pendek, } \\
\text { durasi NREM } 3 \text { lebih panjang } \\
\text { dibandingkan musik klasik dan } \\
\text { tanpa stimulus, efisiensi tidur naik } \\
\text { menjadi } 95.76 \%\end{array}$ & $\begin{array}{l}\text { Kualitas tidur musik klasik dan } \\
\text { alam lebih baik dibandingkan } \\
\text { dengan tanpa stimulus }\end{array}$ \\
\hline
\end{tabular}

14,17\%. Tidur sambil mendengarkan musik menjadi lebih rileks dan menambah efisiensi kualitas tidur.

Tabel 3 merupakan penjelasan rinci untuk setiap subjek. Pemberian stimulus musik klasik memiliki kualitas tidur lebih baik pada subek 2 , subjek 3 , subjek 4 , subjek 5 , subjek 6 , subjek 7 , dan subjek 8 , sedangkan pemberian stimulus musik alam memiliki kualitas tidur lebih baik pada subjek 1, subjek 2, subjek 3, subjek 5, subjek 6 , subjek 8 , dan subjek 9 .

\subsection{Analisis Data dengan Uji Kesamaan Dua Rata- rata}

Tabel 4 dan Tabel 5 berturut-turut menunjukkan hasil uji kesamaan dua rata-rata untuk pengaruh musik klasik dan musik alam. Analisis uji kesamaan dua rata-rata digunakan untuk melihat apakah terdapat pengaruh stimulus musik terhadap tanpa stimulus di setiap tahapan tidur. Hipotesis pada uji ini, yaitu:

- $\mathrm{HO}=$ Tidak terdapat pengaruh antara stimulus musik terhadap kondisi tanpa stimulus

- $\mathrm{Ha}=$ Terdapat pengaruh antara stimulus musik 
Tabel 4. Hasil Uji Kesamaan Dua Rata-Rata dengan Stimulus Musik Klasik

\begin{tabular}{|c|c|c|c|c|c|c|c|c|}
\hline & \multicolumn{2}{|c|}{ Sleep Latency } & \multicolumn{2}{|c|}{ NREM tahap 1 } & \multicolumn{2}{c|}{ NREM tahap 2 } & \multicolumn{2}{c|}{ NREM tahap 1 } \\
\hline & & & & & & & \\
\hline Mean & 187.8889 & 125.5556 & 2135.8889 & 2193.5556 & 1556.5556 & 1842.2222 & 246.8889 & 668.7778 \\
T hitung & 0.9529797 & & -0.1554718 & & -1.3428421 & & -2.3717928 & \\
T tabel & 2.306 & & 2.306 & & 2.306 & & 2.306 & \\
\hline Keterangan & \multicolumn{2}{|c|}{ Ho diterima } & \multicolumn{2}{|c|}{ Ho diterima } & Ho diterima & \multicolumn{2}{c|}{ Ho ditolak } \\
\hline
\end{tabular}

Tabel 5. Hasil Uji Kesamaan Dua Rata-Rata dengan Stimulus Musik Alam

\begin{tabular}{|c|c|c|c|c|c|c|c|c|}
\hline & \multicolumn{2}{|c|}{ Sleep Latency } & \multicolumn{2}{|c|}{ NREM tahap 1 } & \multicolumn{2}{c|}{ NREM tahap 2 } & \multicolumn{2}{c|}{ NREM tahap 1 } \\
\hline & & & & & & & \\
\hline Mean & 187.8889 & 86.5556 & 2135.8889 & 2460.6667 & 1556.5556 & 2011.5556 & 246.8889 & 381.4444 \\
T hitung & 1.4242135 & & -0.8672152 & & -1.7226199 & & -0.692647 & \\
T tabel & 2.306 & & 2.306 & & 2.306 & & 2.306 & \\
\hline Keterangan & \multicolumn{2}{|c|}{ Ho diterima } & \multicolumn{2}{|c|}{ Ho diterima } & \multicolumn{2}{c|}{ Ho diterima } & \multicolumn{2}{c|}{ Ho diterima } \\
\hline
\end{tabular}

Tabel 6. Hasil F-test dengan Musik Klasik

\begin{tabular}{|c|c|c|c|c|c|c|c|c|}
\hline & \multicolumn{2}{|c|}{ Sleep Latency } & \multicolumn{2}{|c|}{ NREM tahap 1 } & \multicolumn{2}{c|}{ NREM tahap 2 } & \multicolumn{2}{c|}{ NREM tahap 1 } \\
\hline Varian & 20059.278 & 18445.611 & 1024242.11 & 213951.778 & 308747.778 & 98549.694 & 194181.994 & 90582.111 \\
T hitung & 1.08748 & & 4.78726 & & 3.13291 & & 2.14371 & \\
T tabel & 3.438 & & 3.438 & & 3.438 & & 3.438 & Ho diterima \\
\hline Keterangan & \multicolumn{2}{|c|}{ Ho diterima } & \multicolumn{2}{|c|}{ Ho ditolak } & Ho diterima & \multicolumn{2}{c|}{ Ho } \\
\hline
\end{tabular}

Tabel 7. Hasil F-test dengan Musik Alam

\begin{tabular}{|c|c|c|c|c|c|c|c|c|}
\hline & \multicolumn{2}{|c|}{ Sleep Latency } & \multicolumn{2}{|c|}{ NREM tahap 1} & \multicolumn{2}{|c|}{ NREM tahap 2} & \multicolumn{2}{|c|}{ NREM tahap 1} \\
\hline Varian & 27115.778 & 18445.611 & 1024242.11 & 238054.25 & 319146.278 & 308747.78 & 249060.278 & 90582.111 \\
\hline T hitung & 1.47004 & & 4.30256 & & 1.03367 & & 2.74955 & \\
\hline $\mathrm{T}$ tabel & 3.438 & & 3.438 & & 3.438 & & 3.438 & \\
\hline Keterangan & \multicolumn{2}{|c|}{ Ho diterima } & \multicolumn{2}{|c|}{ Ho ditolak } & \multicolumn{2}{|c|}{ Ho diterima } & \multicolumn{2}{|c|}{ Ho diterima } \\
\hline
\end{tabular}

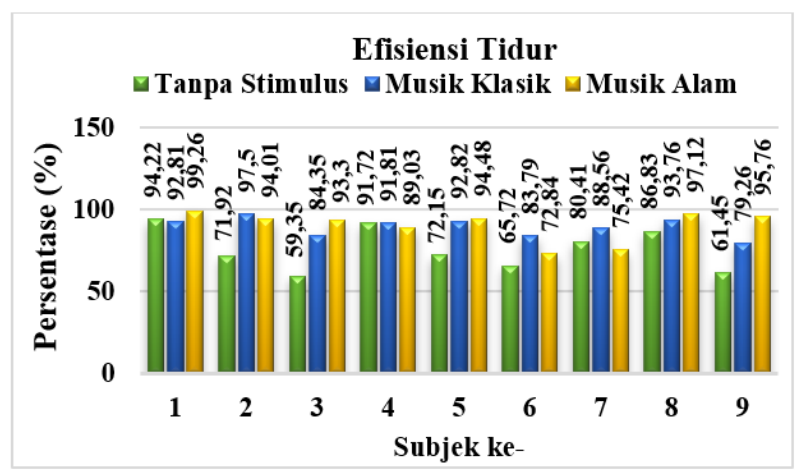

\section{Gambar 9. Grafik Hasil Efisiensi Tidur}

terhadap kondisi tanpa stimulus

Secara keseluruhan, uji kesamaan dua rata-rata diketahui bahwa tidak terdapat pengaruh subjek yang diberi stimulus musik terhadap kondisi tanpa stimulus karena $\mathrm{t}$ hitung $<\mathrm{t}$ tabel, kecuali pada NREM tahap 3 dengan stimulus musik klasik, yaitu mengalami durasi yang lebih panjang. NREM tahap 3 merepresentasikan tingkat kedalaman tidur (deep sleep), maka persentase deep sleep dengan stimulus musik klasik lebih baik dibandingkan dengan tanpa stimulus dan musik alam. Semakin tinggi persentase deep sleep, maka semakin baik kualitas tidurnya.

\subsection{Analisis Data dengan $F$-test}

Tabel 6 dan Tabel 7 menunjukkan hasil uji F-test untuk musik klasik dan musik alam secara berturut-turut. Analisis $F$-test ini digunakan untuk membandingkan penyebaran dua set data dengan membandingkan nilai vvarians, untuk melihat nilai-nilai yang tersebar pada setiap tahapan tidur dan melihat apakah ada perbedaan antar perlakuan. Hipotesis pada $F$-test ini yaitu:

- $\mathrm{HO}=$ Tidak terdapat perbedaan antara stimulus musik terhadap kondisi tanpa stimulus

- $\mathrm{Ha}=$ Terdapat perbedaan antara stimulus musik terhadap kondisi tanpa stimulus, dari uji F-test dapat diketahui perbedaan antara subjek yang diberi stimulus musik klasik maupun musik alam, terhadap kondisi tanpa stimulus pada NREM tahap 1. 
Secara keseluruhan dengan uji F-test diketahui bahwa terdapat perbedaan secara signifikan antara subjek yang diberi stimulus musik klasik maupun alam terhadap kondisi tanpa stimulus pada NREM tahap 1 karena $\mathrm{F}$ hitung $>\mathrm{F}$ tabel. NREM tahap 1 dengan stimulus musik klasik maupun musik alam memiliki durasi lebih panjang. Semakin panjang durasi NREM tahap 1, maka semakin baik kualitas tidurnya.

\section{Kesimpulan}

Pada penelitian ini telah dilakukan analisis kualitas tidur dengan 3 kondisi, yaitu tanpa stimulus, pemberian musik klasik, dan pemberian musik alam. Metode yang digunakan adalah uji kesamaan dua rata-rata dan $F$-test, dan didapatkan kesimpulan sebagai berikut:

1. Hasil uji kesamaan dua rata-rata menunjukkan adanya pengaruh subjek yang diberi stimulus musik klasik pada NREM tahap 3, karena nilai t hitung $>$ t tabel, Durasi NREM tahap 3 musik klasik lebih panjang daripada tanpa stimulus, maka persentase deep sleep dengan musik klasik lebih baik dibandingkan dengan tanpa stimulus dan musik alam. Semakin tinggi persentase deep sleep, maka semakin baik kualitas tidurnya.

2. Hasil uji $F$-test menunjukkan adanya perbedaan secara signifikan antara subjek yang diberi stimulus musik klasik maupun alam pada NREM tahap 1, karena nilai $\mathrm{F}$ hitung $>F$ tabel. Durasi NREM tahap 1 lebih panjang. NREM tahap 1 dengan stimulus musik klasik maupun musik alam memiliki durasi lebih panjang. Semakin panjang durasi NREM tahap 1, maka semakin baik kualitas tidurnya.

3. c. Pemberian stimulus musik klasik dan musik alam memiliki persentase keberhasilan 87,5

\section{Pustaka}

[1] A. Rizal, "Instrumentasi biomedis," Yogyakarta: Graha Ilmu, 2014.

[2] S. Štolc, A. Krakovská, and M. Teplan, "Audiovisual stimulation of human brain linear and nonlinear measures," Measurement Science Review, vol. 3, 2003.

[3] D. Esti, M. A. Suhendra, and M. I. R, "Effect of sundanese music on daytime sleep quality based on eeg signal," Proceeding The 3rd Padjajaran International Physics Symposium, 2017.

[4] N. Nursalam, J. Haryanto, R. Indarwati, and E. D. Wahyuni, "Musik langgam jawa dalam upaya pemenuhan kebutuhan tidur lansia," Jurnal Ners, vol. 2, no. 2, pp. 124-128, 2017.

[5] N. Indrawati, "Perbandingan kualitas tidur mahasiswa yang mengikuti ukm dan tidak mengikuti ukm pada mahasiswa reguler fik ui," Diakses dari http://lib. ui. ac. id/file, 2012.

[6] N. R. Carlson, Physiology of behavior. Pearson Higher Ed, 2012.

[7] V. P. Sagala, "Kualitas tidur dan faktor-faktor gangguan tidur pada penderita hipertensi di wilayah kerja puskesmas medan johor,” 2011.

[8] "Normal sleep eeg." [Online]. Available: https:// search.medscape.com/search/?q=NormalSleepEEG

[9] E. Webmaster. [Online]. Available: http://www. ers-education.org/lrmedia/2016/pdf/298830

[10] P. B. Santosa et al., "Analisis statistik dengan microsoft excel dan spss," Yogyakarta: Andi, 2005.

[11] S. Singgih, "Statistik parametrik konsep dan aplikasi dengan spss," Jakarta: Penerbit PT Elex Media Komputindo Kelompok Gramedia, Anggota IKAPI, 2010.

[12] N. Sudjana, "Metode statistika," Bandung: Tarsito, vol. 168, 2005.

[13] A. Widarjono, "Statistika terapan dengan excel \& spss," Yogyakarta: UPP STIM YKPN, 2015. 